\title{
Article
}

\section{Tax Progressivity of Personal Wages and Income Inequality}

\author{
Nikolaos Papanikolaou
}

check for

updates

Citation: Papanikolaou, Nikolaos. 2021. Tax Progressivity of Personal Wages and Income Inequality. Journal of Risk and Financial Management 14: 60. https://doi.org/10.3390/ jrfm14020060

Academic Editor: Thanasis Stengos

Received: 8 January 2021

Accepted: 29 January 2021

Published: 2 February 2021

Publisher's Note: MDPI stays neutral with regard to jurisdictional claims in published maps and institutional affiliations.

Copyright: (C) 2021 by the author. Licensee MDPI, Basel, Switzerland. This article is an open access article distributed under the terms and conditions of the Creative Commons Attribution (CC BY) license (https:// creativecommons.org/licenses/by/ $4.0 /)$.
Department of Economics and Business, Lehman College-CUNY, Bronx, NY 10468, USA; nikolaos.papanikolaou@lehman.cuny.edu

\begin{abstract}
The paper examines tax progressivity and income inequality using Census Bureau Current Population Survey (CPS) personal income data. The Kakwani index is used to derive tax progressivity for All, Male, Female, White and African American personal wage income of CPS respondents, respectively. The tax progressivity results show a tax system that is partly progressive and mostly regressive. Due to its regressive nature, the tax system did not display tax progressivity for the entire period under analysis for personal wage income respondents as well as when broken-down by race and gender in the United States for years 1996 to 2011.
\end{abstract}

Keywords: tax progressivity; Kakwani index; current population survey; personal wage; inequality

\section{Introduction}

Tax policy (i.e., regressive, proportional and progressive) and tax progressivity has its roots in Classical Economics and in the writings of Adam Smith's Wealth of Nations (Smith 1776) and John Stuart Mill's Principles of Political Economy (Mill 1896). In the case of Smith, he wrote in Chapter II, of the Sources of the General or Public Revenue of the Society, Part 2 of Taxes, in the Wealth of Nations:

"[t]he subjects of every state out to contribute towards the support of the government, as nearly possible, in proportion of their respective abilities that is; in proportion to the revenue which they respectively enjoy under the protection of the state."

Thus, for Smith tax policy was twofold: First, that taxes levied should be applied proportionally for the majority of the population. Secondly, top income groups the marginal tax rate should increase for each additional dollar of income beyond an upper limit. The case of J.S. Mill he argued that individuals earning a subsistence level of income should be exempt from taxation. In addition, taxation can be used as a redistribution tool to transfer money income from high to lower income earners.

J. S. Mill is indifferent to redistribution as long as it does not interfere with productive processes. In fact, he is most concerned with a distribution that maximizes, for members of society, the goals of human freedom (and security). Thus, mild redistribution that does not interfere with productive efficiency but promotes greater freedom is certainly desirable. Certainly, as long as monetary transfers through taxes do not create work disincentives, for Mill, there is no limit to how much can be redistributed through direct transfers. (Matthewson 2001, p. 10)

Tax progressivity is a by-product of tax policy. The type of tax policy that is implemented has a direct effect on the macroeconomy and income inequality. The three major tax options are a regressive tax which the percentage of income paid in taxes decreases as income increases. While a progressive tax the percentage of income paid in taxes increases as income increases. A proportional tax of income paid in taxes is fixed as income changes. Therefore, tax progressivity costs and benefits depend on government tax policy which has a direct effect on economic growth, economic stability, full employment, equity (equal opportunity versus equal outcome), and social welfare. Therefore, there is a close link between the tax progressivity and inequality in net income. 
This paper contributes to the empirical literature on tax-progressivity and income inequality, which includes (Musgrave and Thin 1948; Dalton 1954; Kakwani 1977a; Kakawani 1977b; Reynolds and Smolensky 1977; Atkinson 1980; Suits 1977). The paper uses the same framework employed by (Kakwani 1977a) to investigate the effect of tax progressivity on income inequality. However, it differs from them in two important ways. The first is through the treatment of tax progressivity using the Census Bureau's Current Population Survey (CPS) personal wage income by all, race, and gender respondents. Previous studies investigated the relationship between tax progressivity on income inequality using Internal Revenue Service data and excluded any empirical analysis based on race or gender. Secondly, the time-period encompasses 1996 to 2011 and therefore, shows the effect of tax progressivity on income inequality before and after the Great Recession 2008-2009.

\section{Related Literature}

Tax policy and tax progressivity were addressed on many fronts. (Blakey 1938) connected tax policy and income inequality and advocated for a progressive tax system. (Vickrey 1947) stressed that changes in the lower and upper parts of the income distribution should not be volatile and the ratio should reflect degree of change consistent with tax policy. (Musgrave and Thin 1948) stressed the importance of government in supporting a tax system that is equitable and based on four general measures of progressivity, average rate progressivity, marginal rate progressivity, liability progressivity, and residual income progressivity. Moreover, Musgrave and Thin examined the effects of before-and-after income tax to analyze the affects in income inequality due to tax policy.

From the nineteen fifties to late nineteen seventies tax progressivity focused on income inequality and economic growth. (Dalton 1954), proposed tax progressivity as a global measure and stressed the correlation with the level of progressivity and its effects on income inequality. (Musgrave 1959) studied the association between progressivity and economic growth. He argued that economic growth depends on factors such as the rate of capital formation such as the savings, and investment levels. Therefore, the tax rates have a direct influence on disposable income and spending behavior and incentives to save or invest. The key according to Musgrave is the level of tax progressivity and its redistribution of income levied before and after taxes. (Atkinson 1970) formalized progressivity and income inequality by deriving a theoretical measure of inequality and income distribution. Atkinson's measure paved the way to the development of the theory of optimal income taxationby (Mirrlees 1971; Suits 1977; Kakawani 1977b; Reynolds and Smolensky 1977; Atkinson 1980; Plotnick 1981; Lambert 2001; Ochmann and Peichl 2006). Tax policy whether progressive, proportional regressive has an impact on the distribution and redistribution of income and inequality and therefore, a direct link to the macroeconomy. (Auerbach and Feenberg 2000) state that tax progressivity in conjunction with fiscal policys can mitigate economic output fluctuations. Furthermore, tax progressivity can also address four decades of wage stagnation and subsequent income inequality (Madrick and Papanikolaou 2010).

(Auten et al. 2016) analyze tax legislation such as the Tax Reform Act of 1969, the Tax Reform Act of 1986, the Omnibus Budget Reconciliation Act of 1993, and the American Taxpayer Relief Act of 2012 of high-income earners and tax reforms. Their finding show that high-income taxpayers responded to the higher capital gains tax rates by reducing realizations. (Elwell et al. 2020) examine economic inequality in the United States using government cash benefits, employer benefits, barriers to economic opportunity, income mobility, regressive and progressive taxes. Their research indicate that tax policy does not adequately address the issue of income inequality and make the connection between income inequality and unequal opportunities, especially in education. (Mathews 2014) study how the degree of progressivity of the U.S. Federal Income Tax has changed over time. The finding shows a degree of progressivity has varied greatly and taxation outcomes are less progressive than prior to the 1940s. (Piketty et al. 2014) use an optimal top tax rate model of top earners and its effects on tax progressivity through three channels: labor supply, tax avoidance, and compensation bargaining. The optimal top tax rate increases 
when there are zero-sum compensation-bargaining effects. Their findings show a decline in tax progressivity when top tax rate cuts are associated with top one percent pretax income shares in-creases but not higher economic growth. (Saez and Zucman 2016) use income tax returns with macroeconomic household balance sheets to examine income inequality since 1913 in the United States. The findings show that wealth concentration was high in the beginning of the twentieth century, fell from 1929 to 1978 , and has continuously increased since then. The top $0.1 \%$ wealth share has risen from $7 \%$ in 1978 to $22 \%$ in 2012, a level almost as high as in 1929. (Wu 2020) states that economic changes explain $61 \%$ of the reduction in tax progressivity observed. Factors such as an aging population and declining gender gap demand less progressive income tax. Furthermore, changing idiosyncratic risks and the declines of labor share and interest rate have the opposite effects while a rising skill premium is about neutral in this regard. The remaining reduction in progressivity implies a shift in the government's weights towards high-ability households

A progressive tax system is associated with a decrease in income inequality, while regressive tax rates will be reflected by an increase in income inequality. When income inequalities of the before-tax and after-tax incomes are identical, then the tax system is proportional. Tax policy according to (Kakwani 1977a) is based on proportionality and that subjects of every state out to contribute towards the support of the government, as nearly possible, in proportion of their respective abilities and in proportion to the revenue which they respectively enjoy under the protection of the state. The Kakwani model is used in this paper to analyze tax progressivity and income inequality.

\section{Materials and Methods}

The empirical research in this paper and its subsequent results are derived from raw income data obtained from the Census Bureau's Current Population Survey (CPS) for years 1996 to 2011. The Census Bureau gathers a wealth of information on income and other socioeconomic indicators of the United States population. The March survey contains the Annual Demographic File and Income Supplement, which report the income-related socioeconomic indicators of individuals, families and households in detail. In this paper, I specifically analyze the distribution of personal wage income of full-time respondents from 1996 to 2011. The Census Bureau defines personal wage income of workers that receive wages, salary, commission, tips or pay in kind from private employer or from a government unit. Also included are persons who are self-employed in an incorporated business.

The Census Bureau conducts several household surveys that measure the economic situation of people (classified as personal or individual), families, and households in the United States. The basic Current Population Survey (CPS) takes place every month. Its primary focus is to collect information on current employment status. In March of every year, a supplementary questionnaire gathers information about income received during the previous calendar year. The March CPS interviewed people in approximately 60,000 households from 1991 until 1996. In 1997, the sample size decreased to 50,000 households. Besides the change in sample size, a new sample design was introduced, and the survey was converted from a paper questionnaire to a computerized instrument in March 1994. In addition, weights based on the results of the 1990 Census were introduced in 1993. Currently, the Current Population Survey (CPS) is a monthly survey of about 50,000 households conducted by the Census Bureau primarily for the Bureau of Labor Statistics.

\subsection{Top-Coding CPS Income Data}

The March Current Population Survey public use files are top coded since 1976 to protect the identity of individuals with high incomes. According to (Burkhauser et al. 2008) top-code income cutoff vary among indicated years and specified by the Census Bureau. In addition, the data analyzed in this paper removed individuals earning zero wage and salary income and top coded according to the Census Bureau's policy. 


\subsection{CPS Data Variables}

Personal wage income is extracted from NBER Current Population Survey CPS supplements ${ }^{1}$ raw March Income data. The CPS March Survey data income variables used for analysis are A-RACE, A-SEX, WSAL-VAL, WKSWORK, A-USLHRS, OCCUP, LJCW, WAGEOTR, ERN-SRCE, ERN-VAL, WS-VAL, FEDTAX_AC and FEDTAX_BC. ${ }^{2}$ Moreover, Self-employed and non-business incorporated respondents are excluded from analysis to focus on respondents that earn a wage primarily from an employer.

\subsection{Tax Progressivity}

To better understand income distributions in the whole range, nonparametric and parametric models are often applied to fit economic data. In this paper, I use the Kakwani index which uses the Lorenz curve, Concentration curve and Gini coefficient to analyze tax progressivity and income inequality.

The Lorenz Curve Equation (1) is defined as a continuously distributed variable $y$ which plots the cumulative total of $y$ divided by the total population size against $p=F(y)$, the cumulative distribution function. Mathematically, the point coordinates are given by $p(y), L(p(y))$,

$$
p(y)=F(y), L(p(y))=\int_{0}^{y} x f(x) d x
$$

with, $f(x)=\frac{d F(x)}{d x}$. In the case of discrete data, the points $y_{1 \ldots}, y_{N}$, where observations have been ordered so that $y_{1} \leq y_{2} \leq \ldots \leq y_{N}$, we get Equation (2),

$$
p(i)=\frac{i}{N}, L\left(p\left(y_{i}\right)\right)=\frac{\sum_{j=1}^{i} y_{j}}{N}
$$

which is analogously for weighted data. Equation (3) compares two income distributions i.e., pre-tax income $y$ as defined in Equation (2) and another variable $t$ defined as post-tax income and observe $y$ and $t$ jointly against $p=F(y)$, the cumulative distribution function we get the concentration curve of $t$ against $y$. The points observed represent a set of pairs $\left(y_{1}, t_{1}\right), \ldots,\left(y_{N}, t_{N}\right)$ indexed in such a way that $y_{1} \leq y_{2} \leq \ldots \leq y_{N}$, the coordinates of the concentration curve are $p\left(y_{i}, t_{i}\right)=\frac{i}{N}$,

$$
C\left(p\left(y_{i}, t_{i}\right)\right)=\frac{\sum_{j=1}^{i} t_{j}}{\sum_{j=1}^{N} t_{j}}=\sum_{j=1}^{i} \frac{t_{j}}{\frac{\mu_{t}}{N}}
$$

where $\mu_{t}$ is the mean of $t$.

\subsection{The Kakwani Model}

(Kakwani 1977a) pioneering paper, Measurement of Tax Progressivity: An International Comparison examined issues associated with deriving a measure for tax progressivity and public expenditure. Kakwani,'s approach differed from prior research on tax progressivity by (Dalton 1954; Slitor 1948; Musgrave and Thin 1948; Bracewell-Milnes 1971), because it applied average tax rates to determine the effects of tax progressivity and public expenditure. I apply Kakwani's index of tax progressivity to CPS personal wage income for All, Male, Female, White and African American, respondents. The goal is to examine tax policy, tax progressivity and its effects on income inequality from a socioeconomic perspective.

Kakwani's model is defined as follows; Equation (4), we let $\mathrm{T}(\mathrm{w})$ be the tax paid by a CPS personal wage income respondent with income w. According to Kakwani, the tax system is progressive when the elasticity is greater than one, regressive when elasticity is less than one, proportional when elasticity is equal to one. In other words, a tax system is

\footnotetext{
https: / / data.nber.org/data/current-population-survey-data.html.
}

2 See Appendix A-Table A1 for variable definitions. 
progressive, proportional and regressive when the marginal tax rate is greater, equal and less than the average tax rate, respectively.

$$
\frac{d t(w)}{d w}=\frac{m(w)-t(w)}{w}
$$

Equation (5) measures tax progressivity, where $t(w)$ is the average tax rate at the wage income $\mathrm{w}$ and $m(w)$ is the marginal tax rate at the same level of wage income. Hence, tax progressivity is derived by comparing pre-tax and post-tax wage income distributions. Therefore, a progressive tax system is associated with a decrease in income inequality. For regressive tax system income inequality increase and for proportional tax system, income inequality is constant. This leads to the Gini coefficient of pre-tax and post-tax wage income as a key measure of income inequality and a measure of tax progressivity. The measure of tax progressivity in this section applies the methodology that the disposable wage income of a unit with income $\mathrm{w}$ is given by

$$
d(w)=w-T(w)
$$

Then pre-tax $(G)$ and post-tax $\left(G^{*}\right)$ Gini coefficient Equation (6) indices and the average tax rate $(t)$

$$
G^{*}=G-\frac{t P}{(1-t)}
$$

Therefore, post-tax wage income inequality consists of three factors, pre-tax wage income, the average tax rate and tax progressivity $(p)$. The post-tax wage income elasticity relating to the post-tax Gini coefficient as it corresponds to tax progressivity and defined in Equations (7) and (8), respectively.

$$
\eta_{t}=\frac{P t}{(1-t)^{2} \times G^{*}}
$$

and

$$
\eta_{p}=\frac{P t}{(1-t) \times G^{*}}
$$

Hence, Equations (7) and (8) illustrate that for a progressive tax system income inequality decreases and a regressive tax system income inequality increases with a rising average tax rate $(t)$ and tax progressivity $(p)$. Furthermore, the ratio $\left(\frac{\eta_{t}}{\eta_{p}}\right)$ measures the elasticity in absolute terms that post-tax wage income is more sensitive to the average tax rate $(t)$ than to tax progressivity $(p)$.

If we differentiate Equations (7) and (8) with respect to $\left(G^{*}\right)$ we get,

$$
\frac{d G^{*}}{G^{*}}=\frac{G}{G^{*}} \times \frac{d G}{G}+\eta_{p} \times \frac{d P}{P}+\eta_{t} \times \frac{d t}{t}
$$

Therefore, Equation (9) shows the decomposition of the percentage change in the post-tax wage income in relation to the percentage changes in pre-tax wage income, tax progressivity and the average tax rate. We define tax progressivity as the difference between pre-tax and post-tax Gini coefficient, $\left(G-G^{*}\right)$.

The concentration index of the $i$ th $\operatorname{tax}, T_{1}(w), T_{2}(w), \ldots, T_{n}(w)$

$$
C=\sum_{i=1}^{n} \frac{t_{i}}{t} \times C_{i}
$$

The tax progressivity of the $i$ th tax,

$$
P=\sum_{i=1}^{n} \frac{t_{i}}{t} \times P_{i}
$$


Equation (12) combines Equations (10) and (11) to analyze the percentage contribution of each tax unit to the total tax progressivity which provides the decomposition of the percentage change in income in terms of the contribution of each tax unit. If $P(i)$ is positive the contribution of the $i$ th tax is negative and if $P(i)$ is negative, the contribution is positive. (Kakwani 1977a, pp. 73-74)

$$
\frac{G^{*}-G}{G}=-\frac{\sum_{i=1}^{n} P_{i} t_{i}}{(1-t) \times G}
$$

\section{Results}

What does it mean to have a progressive tax system? The definition of a progressive tax is that it takes a larger percentage of income from the high-income earners than it does from the low-income earners. Therefore, a progressive tax system is effectually a means to redistribute income from the high-income earners to the low-income earners. Subsequently, the government revenues collected from a progressive tax system can be used to fund social programs that are designated for the lower income groups for a more equitable society. A proportional and regressive tax system differs in that a proportional tax i.e., a flat tax which treats varying incomes the same irrespective of high-or low-income earners and a regressive tax system takes fewer taxes as a percentage as the marginal income increase.

The method derives a tax progressivity index used to measure income inequality for All, Male, Female, White and African American CPS respondents, respectively. In Tables 1-6 gives the progressivity index under study. The index considers before-and-after tax personal wage income which combines the Lorenz curve, Concentration curve and Gini coefficient to derive an appropriate measure of tax progressivity.

Tax progressivity was calculated by deriving pre-tax CPS personal wage income and applying the Gini coefficient and the concentration index of the total tax amounts paid which determines post-tax CPS personal wage income. The numerical results on tax progressivity for CPS personal wage income for All, Male, Female, White and African American respondents are presented in Tables 2-6, respectively. The first column gives the years under study. Columns two and three gives the pre-tax $(G)$ and post-tax $\left(G^{*}\right)$ Gini coefficients. Columns 4 and 5 gives the post-tax concentration index and average tax rate. Columns 6, 7 and 8 gives the tax progressivity index $(\mathrm{P})$, progressivity elasticity $(\mathrm{p})$ and tax elasticity $(\mathrm{t})$, respectively. Columns 9 to 12 gives percentage changes of pre-tax Gini, post-tax Gini, progressivity and the average tax rate, respectively.

The results given in Tables 1-5 show the distributional measures of all CPS personal wage income and tax progressivity for years 1996 to 2011.

\subsection{All CPS Respondents}

Table 1 displays all CPS respondents' tax progressivity. The highest level of tax progressivity was during years 2005, 28.5\% and 2006, 23.8\% while the lowest level was in $2000,16.3 \%$ while the average tax rates $2000,-10.5 \%$ and 2005 and $2006,-11.1$ and $-11.7 \%$, respectively. 
Table 1. Tax progressivity for all CPS respondents for years 1996 to 2011.

\begin{tabular}{|c|c|c|c|c|c|c|c|c|c|c|c|}
\hline Year & $\begin{array}{l}\text { Pre-Tax } \\
\text { Gini } \\
\text { Index } \\
\text { (G) }\end{array}$ & $\begin{array}{c}\text { Post- } \\
\text { Tax } \\
\text { Gini } \\
\text { Index } \\
\left(G^{*}\right)\end{array}$ & $\begin{array}{c}\text { Post-Tax } \\
\text { Concentration } \\
\text { Index }\end{array}$ & $\begin{array}{l}\text { Average } \\
\text { Tax } \\
\text { Rate }(t)\end{array}$ & $\begin{array}{l}\text { Progressivity } \\
\text { Index (p) }\end{array}$ & $\begin{array}{c}\text { Progressivity } \\
\text { (Elasticity) } \\
\eta(p)\end{array}$ & $\begin{array}{c}\text { Tax } \\
\text { (Elasticity) } \\
\eta(t)\end{array}$ & $\begin{array}{c}\text { \% Change } \\
\text { Due to } \\
\text { Pre-Tax } \\
\text { Gini Index }\end{array}$ & $\begin{array}{c}\text { \% Change } \\
\text { Due to } \\
\text { Post-Tax } \\
\text { Gini Index }\end{array}$ & $\begin{array}{l}\% \text { Change } \\
\text { Due to } \\
\text { Progressivity }\end{array}$ & $\begin{array}{c}\% \\
\text { Change } \\
\text { Due to } \\
\text { Tax } \\
\text { Rate }\end{array}$ \\
\hline 1996 & 0.469 & 0.450 & 0.248 & -0.082 & 0.221 & 0.037 & -0.034 & NA & NA & NA & NA \\
\hline 1997 & 0.474 & 0.453 & 0.256 & -0.090 & 0.218 & 0.040 & -0.036 & 1.10 & 0.64 & -1.21 & 9.50 \\
\hline 1998 & 0.472 & 0.449 & 0.265 & -0.093 & 0.207 & 0.039 & -0.036 & -0.51 & -0.84 & -5.21 & 3.23 \\
\hline 1999 & 0.466 & 0.444 & 0.248 & -0.096 & 0.218 & 0.043 & -0.039 & -1.31 & -1.21 & 5.32 & 3.66 \\
\hline 2000 & 0.478 & 0.448 & 0.315 & -0.105 & 0.163 & 0.035 & -0.031 & 2.57 & 0.86 & -25.20 & 9.04 \\
\hline 2001 & 0.484 & 0.459 & 0.305 & -0.091 & 0.179 & 0.032 & -0.030 & 1.36 & 2.45 & 9.77 & -13.44 \\
\hline 2002 & 0.494 & 0.463 & 0.305 & -0.113 & 0.189 & 0.041 & -0.037 & 1.97 & 0.89 & 5.55 & 24.01 \\
\hline 2003 & 0.493 & 0.461 & 0.301 & -0.119 & 0.193 & 0.045 & -0.040 & -0.10 & -0.36 & 2.02 & 5.95 \\
\hline 2004 & 0.474 & 0.448 & 0.244 & -0.118 & 0.230 & 0.054 & -0.049 & -3.94 & -2.85 & 19.53 & -0.84 \\
\hline 2005 & 0.472 & 0.452 & 0.187 & -0.117 & 0.285 & 0.066 & -0.059 & -0.40 & 0.96 & 23.96 & -0.85 \\
\hline 2006 & 0.474 & 0.450 & 0.235 & -0.111 & 0.238 & 0.053 & -0.048 & 0.35 & -0.49 & -16.48 & -5.63 \\
\hline 2007 & 0.491 & 0.464 & 0.284 & -0.104 & 0.207 & 0.042 & -0.038 & 3.73 & 3.19 & -13.01 & -5.96 \\
\hline 2008 & 0.475 & 0.450 & 0.283 & -0.096 & 0.192 & 0.037 & -0.034 & -3.32 & -3.06 & -7.37 & -8.17 \\
\hline 2009 & 0.491 & 0.468 & 0.282 & -0.087 & 0.209 & 0.036 & -0.033 & 3.28 & 3.93 & 8.65 & -8.89 \\
\hline 2010 & 0.496 & 0.472 & 0.284 & -0.093 & 0.212 & 0.038 & -0.035 & 1.08 & 0.81 & 1.41 & 6.31 \\
\hline 2011 & 0.490 & 0.468 & 0.283 & -0.085 & 0.207 & 0.034 & -0.032 & -1.25 & -0.88 & -2.32 & -8.75 \\
\hline
\end{tabular}

\subsection{Male CPS Respondents}

Table 2 displays male CPS respondent's tax progressivity. The highest level of tax progressivity was during years 1997, 22.1\% and 2005, 26.5\% while the lowest level was in $2000,14.1 \%$ while the average tax rates $2000,-7.4 \%$ and 1997 and $2005,7.6$ and $-6.3 \%$, respectively.

Table 2. Tax progressivity for male CPS respondents for years 1996 to 2011.

\begin{tabular}{|c|c|c|c|c|c|c|c|c|c|c|c|}
\hline Year & $\begin{array}{l}\text { Pre-Tax } \\
\text { Gini } \\
\text { Index } \\
\text { (G) }\end{array}$ & $\begin{array}{c}\text { Post- } \\
\text { Tax } \\
\text { Gini } \\
\text { Index } \\
\left(G^{*}\right)\end{array}$ & $\begin{array}{c}\text { Post-Tax } \\
\text { Concentration } \\
\text { Index }\end{array}$ & $\begin{array}{c}\text { Average } \\
\text { Tax } \\
\text { Rate (t) }\end{array}$ & $\begin{array}{l}\text { Progressivity } \\
\text { Index (p) }\end{array}$ & $\begin{array}{c}\text { Progressivity } \\
\text { (elasticity) } \\
\eta(p)\end{array}$ & $\begin{array}{c}\text { Tax } \\
\text { (elasticity) } \\
\eta(t)\end{array}$ & $\begin{array}{c}\text { \% Change } \\
\text { Due to } \\
\text { Pre-Tax } \\
\text { Gini Index }\end{array}$ & $\begin{array}{c}\text { \% Change } \\
\text { Due to } \\
\text { Post-Tax } \\
\text { Gini Index }\end{array}$ & $\begin{array}{l}\text { \% Change } \\
\text { Due to Pro- } \\
\text { gressivity }\end{array}$ & $\begin{array}{c}\% \\
\text { Change } \\
\text { Due to } \\
\text { Tax } \\
\text { Rate }\end{array}$ \\
\hline 1996 & 0.448 & 0.432 & 0.230 & -0.074 & 0.218 & 0.035 & -0.032 & NA & NA & NA & NA \\
\hline 1997 & 0.457 & 0.441 & 0.236 & -0.076 & 0.221 & 0.035 & -0.033 & 2.06 & 1.95 & 1.10 & 2.17 \\
\hline 1998 & 0.455 & 0.440 & 0.254 & -0.062 & 0.201 & 0.027 & -0.025 & -0.48 & -0.08 & -8.88 & -18.28 \\
\hline 1999 & 0.448 & 0.432 & 0.240 & -0.069 & 0.207 & 0.031 & -0.029 & -1.56 & -1.77 & 3.13 & 11.18 \\
\hline 2000 & 0.454 & 0.432 & 0.313 & -0.074 & 0.141 & 0.022 & -0.021 & 1.28 & -0.10 & -32.16 & 8.02 \\
\hline 2001 & 0.472 & 0.456 & 0.310 & -0.055 & 0.162 & 0.018 & -0.018 & 4.05 & 5.53 & 15.35 & -26.18 \\
\hline 2002 & 0.477 & 0.458 & 0.310 & -0.066 & 0.167 & 0.022 & -0.021 & 1.06 & 0.42 & 2.72 & 20.29 \\
\hline 2003 & 0.478 & 0.457 & 0.309 & -0.073 & 0.169 & 0.025 & -0.023 & 0.30 & -0.09 & 1.48 & 10.94 \\
\hline 2004 & 0.460 & 0.444 & 0.252 & -0.068 & 0.208 & 0.030 & -0.028 & -3.92 & -2.99 & 22.94 & -7.05 \\
\hline 2005 & 0.459 & 0.448 & 0.194 & -0.063 & 0.265 & 0.035 & -0.033 & -0.12 & 0.90 & 27.39 & -7.59 \\
\hline 2006 & 0.462 & 0.449 & 0.245 & -0.057 & 0.217 & 0.026 & -0.025 & 0.69 & 0.33 & -17.93 & -9.33 \\
\hline 2007 & 0.474 & 0.460 & 0.295 & -0.051 & 0.179 & 0.019 & -0.018 & 2.65 & 2.47 & -17.67 & -10.29 \\
\hline 2008 & 0.465 & 0.452 & 0.294 & -0.047 & 0.171 & 0.017 & -0.016 & -2.03 & -1.84 & -4.53 & -7.94 \\
\hline 2009 & 0.475 & 0.463 & 0.292 & -0.043 & 0.183 & 0.016 & -0.016 & 2.27 & 2.60 & 7.06 & -8.63 \\
\hline 2010 & 0.480 & 0.465 & 0.294 & -0.057 & 0.187 & 0.022 & -0.021 & 1.05 & 0.25 & 2.00 & 32.87 \\
\hline 2011 & 0.491 & 0.476 & 0.289 & -0.053 & 0.202 & 0.021 & -0.020 & 2.20 & 2.54 & 8.41 & -6.67 \\
\hline
\end{tabular}

\subsection{Female CPS Respondents}

Table 3 displays female CPS respondent's tax progressivity. The highest level of tax progressivity was during years 2005, 29.2\% and 2006, 24.6\% while the lowest level was in $2000,17.2 \%$ while the average tax rates $2000,-16.5 \%$ and 2005 and $2006,-20.1$ and $-19.2 \%$, respectively. 
Table 3. Tax progressivity for female CPS respondents for years 1996 to 2011.

\begin{tabular}{|c|c|c|c|c|c|c|c|c|c|c|c|}
\hline Year & $\begin{array}{l}\text { Pre-Tax } \\
\text { Gini } \\
\text { Index } \\
\text { (G) }\end{array}$ & $\begin{array}{c}\text { Post- } \\
\text { Tax } \\
\text { Gini } \\
\text { Index } \\
\left(G^{*}\right)\end{array}$ & $\begin{array}{c}\text { Post-Tax } \\
\text { Concentration } \\
\text { Index }\end{array}$ & $\begin{array}{l}\text { Average } \\
\text { Tax } \\
\text { Rate (t) }\end{array}$ & $\begin{array}{l}\text { Progressivity } \\
\text { Index (p) }\end{array}$ & $\begin{array}{c}\text { Progressivity } \\
\text { (elasticity) } \\
\eta(p)\end{array}$ & $\begin{array}{c}\text { Tax } \\
\text { (elasticity) } \\
\eta(t)\end{array}$ & $\begin{array}{c}\text { \% Change } \\
\text { Due to } \\
\text { Pre-Tax } \\
\text { Gini Index }\end{array}$ & $\begin{array}{c}\text { \% Change } \\
\text { Due to } \\
\text { Post-Tax } \\
\text { Gini Index }\end{array}$ & $\begin{array}{l}\text { \% Change } \\
\text { Due to Pro- } \\
\text { gressivity }\end{array}$ & $\begin{array}{c}\% \\
\text { Change } \\
\text { Due to } \\
\text { Tax } \\
\text { Rate }\end{array}$ \\
\hline 1996 & 0.461 & 0.439 & 0.244 & -0.099 & 0.217 & 0.044 & -0.040 & NA & NA & NA & NA \\
\hline 1997 & 0.462 & 0.439 & 0.255 & -0.098 & 0.207 & 0.042 & -0.038 & 0.31 & 0.12 & -4.50 & -0.51 \\
\hline 1998 & 0.459 & 0.430 & 0.253 & -0.130 & 0.206 & 0.055 & -0.049 & -0.65 & -2.11 & -0.48 & 32.18 \\
\hline 1999 & 0.454 & 0.423 & 0.234 & -0.152 & 0.220 & 0.069 & -0.060 & -1.17 & -1.64 & 7.05 & 16.95 \\
\hline 2000 & 0.464 & 0.423 & 0.292 & -0.165 & 0.172 & 0.058 & -0.049 & 2.27 & -0.04 & -21.82 & 8.37 \\
\hline 2001 & 0.454 & 0.416 & 0.279 & -0.157 & 0.175 & 0.057 & -0.049 & -2.27 & -1.66 & 1.54 & -4.86 \\
\hline 2002 & 0.468 & 0.424 & 0.277 & -0.194 & 0.192 & 0.073 & -0.061 & 3.24 & 1.81 & 9.47 & 23.64 \\
\hline 2003 & 0.468 & 0.423 & 0.272 & -0.197 & 0.196 & 0.076 & -0.064 & -0.05 & -0.02 & 2.49 & 1.76 \\
\hline 2004 & 0.461 & 0.425 & 0.218 & -0.199 & 0.244 & 0.095 & -0.079 & -1.47 & 0.42 & 24.10 & 0.96 \\
\hline 2005 & 0.456 & 0.428 & 0.164 & -0.201 & 0.292 & 0.114 & -0.095 & -1.25 & 0.71 & 19.87 & 0.96 \\
\hline 2006 & 0.457 & 0.423 & 0.211 & -0.192 & 0.246 & 0.093 & -0.078 & 0.29 & -1.25 & -15.93 & -4.48 \\
\hline 2007 & 0.474 & 0.434 & 0.259 & -0.183 & 0.214 & 0.076 & -0.065 & 3.65 & 2.52 & -12.69 & -4.69 \\
\hline 2008 & 0.457 & 0.420 & 0.259 & -0.166 & 0.197 & 0.067 & -0.057 & -3.57 & -3.17 & -7.96 & -9.28 \\
\hline 2009 & 0.471 & 0.438 & 0.260 & -0.149 & 0.212 & 0.063 & -0.055 & 3.22 & 4.28 & 7.39 & -10.23 \\
\hline 2010 & 0.479 & 0.447 & 0.264 & -0.141 & 0.215 & 0.059 & -0.052 & 1.69 & 2.07 & 1.65 & -5.51 \\
\hline 2011 & 0.463 & 0.433 & 0.268 & -0.126 & 0.196 & 0.051 & -0.045 & -3.32 & -2.99 & -9.02 & -10.24 \\
\hline
\end{tabular}

\subsection{White CPS Respondents}

Table 4 displays white CPS respondent's tax progressivity. The highest level of tax progressivity was during years 2005, 29.2\% and 2006, 24.6\% while the lowest level was in $2000,16.3 \%$ while the average tax rates $2000,-11.7 \%$ and 2005 and $2006,-13.9$ and $-13.3 \%$, respectively.

Table 4. Tax progressivity for white CPS respondents for years 1996 to 2011.

\begin{tabular}{|c|c|c|c|c|c|c|c|c|c|c|c|}
\hline Year & $\begin{array}{l}\text { Pre-Tax } \\
\text { Gini } \\
\text { Index } \\
\text { (G) }\end{array}$ & $\begin{array}{c}\text { Post- } \\
\text { Tax } \\
\text { Gini } \\
\text { Index } \\
\left(G^{*}\right)\end{array}$ & $\begin{array}{c}\text { Post-Tax } \\
\text { Concentration } \\
\text { Index }\end{array}$ & $\begin{array}{c}\text { Average } \\
\text { Tax } \\
\text { Rate (t) }\end{array}$ & $\begin{array}{l}\text { Progressivity } \\
\text { Index (p) }\end{array}$ & $\begin{array}{c}\text { Progressivity } \\
\text { (elasticity) } \\
\eta(p)\end{array}$ & $\begin{array}{c}\text { Tax } \\
\text { (elasticity) } \\
\eta(t)\end{array}$ & $\begin{array}{c}\text { \% Change } \\
\text { Due to } \\
\text { Pre-Tax } \\
\text { Gini Index }\end{array}$ & $\begin{array}{c}\text { \% Change } \\
\text { Due to } \\
\text { Post-Tax } \\
\text { Gini Index }\end{array}$ & $\begin{array}{l}\text { \% Change } \\
\text { Due to Pro- } \\
\text { gressivity }\end{array}$ & $\begin{array}{c}\% \\
\text { Change } \\
\text { Due to } \\
\text { Tax } \\
\text { Rate }\end{array}$ \\
\hline 1996 & 0.470 & 0.450 & 0.246 & -0.089 & 0.224 & 0.041 & -0.037 & NA & NA & NA & NA \\
\hline 1997 & 0.475 & 0.453 & 0.255 & -0.093 & 0.220 & 0.041 & -0.038 & 1.07 & 0.78 & -1.58 & 4.17 \\
\hline 1998 & 0.474 & 0.452 & 0.264 & -0.092 & 0.210 & 0.039 & -0.036 & -0.23 & -0.40 & -4.62 & -0.22 \\
\hline 1999 & 0.468 & 0.444 & 0.246 & -0.105 & 0.222 & 0.047 & -0.043 & -1.34 & -1.64 & 5.68 & 13.65 \\
\hline 2000 & 0.474 & 0.441 & 0.311 & -0.117 & 0.163 & 0.039 & -0.035 & 1.26 & -0.72 & -26.56 & 11.06 \\
\hline 2001 & 0.482 & 0.454 & 0.302 & -0.105 & 0.180 & 0.038 & -0.034 & 1.85 & 2.83 & 10.42 & -10.04 \\
\hline 2002 & 0.493 & 0.458 & 0.301 & -0.131 & 0.192 & 0.049 & -0.043 & 2.20 & 0.98 & 6.64 & 25.10 \\
\hline 2003 & 0.489 & 0.453 & 0.296 & -0.140 & 0.193 & 0.052 & -0.046 & -0.78 & -1.14 & 0.63 & 6.48 \\
\hline 2004 & 0.475 & 0.446 & 0.239 & -0.139 & 0.236 & 0.065 & -0.057 & -2.81 & -1.48 & 22.25 & -0.32 \\
\hline 2005 & 0.475 & 0.453 & 0.183 & -0.139 & 0.292 & 0.079 & -0.069 & -0.06 & 1.50 & 23.89 & -0.32 \\
\hline 2006 & 0.477 & 0.450 & 0.231 & -0.133 & 0.246 & 0.064 & -0.057 & 0.34 & -0.71 & -15.95 & -4.15 \\
\hline 2007 & 0.488 & 0.457 & 0.279 & -0.127 & 0.209 & 0.052 & -0.046 & 2.45 & 1.62 & -14.89 & -4.32 \\
\hline 2008 & 0.479 & 0.449 & 0.278 & -0.119 & 0.200 & 0.047 & -0.042 & -2.02 & -1.72 & -4.26 & -6.72 \\
\hline 2009 & 0.485 & 0.458 & 0.277 & -0.110 & 0.208 & 0.045 & -0.041 & 1.42 & 1.96 & 3.86 & -7.21 \\
\hline 2010 & 0.488 & 0.459 & 0.280 & -0.116 & 0.208 & 0.047 & -0.042 & 0.52 & 0.22 & -0.06 & 5.00 \\
\hline 2011 & 0.484 & 0.457 & 0.278 & -0.107 & 0.205 & 0.044 & -0.039 & -0.89 & -0.50 & -1.17 & -7.18 \\
\hline
\end{tabular}

\subsection{African American Respondents}

Table 5 displays African American CPS respondent's tax progressivity. The highest level of tax progressivity was during years 2004, 17.7\%, 2005, 22.2\% and 2006, 17.7\% while the lowest level was in 2000, 10.5\% while the average tax rates 2000, -3.0\% and 2004, 2005 and $2006,2,-0.9$ and $-1.4 \%$, respectively. 
Table 5. Tax progressivity for African American CPS respondents for years 1996 to 2011.

\begin{tabular}{|c|c|c|c|c|c|c|c|c|c|c|c|}
\hline Year & $\begin{array}{l}\text { Pre-Tax } \\
\text { Gini } \\
\text { Index } \\
\text { (G) }\end{array}$ & $\begin{array}{c}\text { Post- } \\
\text { Tax } \\
\text { Gini } \\
\text { Index } \\
\left(G^{*}\right)\end{array}$ & $\begin{array}{c}\text { Post-Tax } \\
\text { Concentration } \\
\text { Index }\end{array}$ & $\begin{array}{l}\text { Average } \\
\text { Tax } \\
\text { Rate (t) }\end{array}$ & $\begin{array}{l}\text { Progressivity } \\
\text { Index (p) }\end{array}$ & $\begin{array}{c}\text { Progressivity } \\
\text { (elasticity) } \\
\eta(p)\end{array}$ & $\begin{array}{c}\text { Tax } \\
\text { (elasticity) } \\
\eta(t)\end{array}$ & $\begin{array}{c}\text { \% Change } \\
\text { Due to } \\
\text { Pre-Tax } \\
\text { Gini Index }\end{array}$ & $\begin{array}{c}\text { \% Change } \\
\text { Due to } \\
\text { Post-Tax } \\
\text { Gini Index }\end{array}$ & $\begin{array}{l}\text { \% Change } \\
\text { Due to Pro- } \\
\text { gressivity }\end{array}$ & $\begin{array}{c}\% \\
\text { Change } \\
\text { Due to } \\
\text { Tax } \\
\text { Rate }\end{array}$ \\
\hline 1996 & 0.440 & 0.434 & 0.267 & -0.021 & 0.172 & 0.008 & -0.008 & NA & NA & NA & NA \\
\hline 1997 & 0.453 & 0.451 & 0.262 & -0.007 & 0.192 & 0.003 & -0.003 & 3.04 & 3.92 & 11.12 & -65.42 \\
\hline 1998 & 0.428 & 0.420 & 0.265 & -0.029 & 0.163 & 0.011 & -0.010 & -5.61 & -6.83 & -15.11 & 285.14 \\
\hline 1999 & 0.432 & 0.421 & 0.263 & -0.041 & 0.169 & 0.016 & -0.015 & 0.92 & 0.22 & 3.76 & 43.86 \\
\hline 2000 & 0.441 & 0.431 & 0.336 & -0.030 & 0.105 & 0.007 & -0.007 & 2.20 & 2.36 & -37.61 & -26.10 \\
\hline 2001 & 0.441 & 0.437 & 0.316 & -0.012 & 0.125 & 0.003 & -0.003 & -0.14 & 1.31 & 18.47 & -62.05 \\
\hline 2002 & 0.438 & 0.429 & 0.317 & -0.026 & 0.120 & 0.007 & -0.007 & -0.68 & -1.73 & -3.57 & 129.57 \\
\hline 2003 & 0.440 & 0.431 & 0.314 & -0.031 & 0.126 & 0.009 & -0.009 & 0.56 & 0.26 & 4.86 & 18.18 \\
\hline 2004 & 0.436 & 0.431 & 0.260 & -0.020 & 0.177 & 0.008 & -0.008 & -0.82 & 0.18 & 40.11 & -35.90 \\
\hline 2005 & 0.427 & 0.426 & 0.206 & -0.009 & 0.222 & 0.005 & -0.005 & -2.09 & -1.35 & 25.51 & -56.00 \\
\hline 2006 & 0.430 & 0.427 & 0.253 & -0.014 & 0.177 & 0.006 & -0.006 & 0.69 & 0.27 & -20.16 & 63.64 \\
\hline 2007 & 0.432 & 0.428 & 0.301 & -0.013 & 0.131 & 0.004 & -0.004 & 0.46 & 0.42 & -25.79 & -11.11 \\
\hline 2008 & 0.433 & 0.437 & 0.300 & 0.014 & 0.132 & -0.004 & 0.004 & 0.08 & 1.93 & 0.61 & -205.47 \\
\hline 2009 & 0.440 & 0.444 & 0.300 & 0.012 & 0.140 & -0.004 & 0.004 & 1.79 & 1.65 & 6.20 & -12.59 \\
\hline 2010 & 0.444 & 0.445 & 0.297 & 0.002 & 0.147 & 0.000 & 0.000 & 0.91 & 0.20 & 4.92 & -87.29 \\
\hline 2011 & 0.441 & 0.444 & 0.301 & 0.011 & 0.141 & -0.003 & 0.003 & -0.70 & -0.07 & -4.49 & 613.33 \\
\hline
\end{tabular}

\subsection{Tax Progressivity: Race and Gender}

When comparing tax progressivity for years 1996 to 2011 by race and gender the CPS income data shows that the average tax progressivity for all respondents is $21.1 \%$ with an average tax of $-10.1 \%$. For male respondents, average tax progressivity $19.4 \%$ with an average tax rate of $-6.2 \%$. Female respondents average tax progressivity of $21.3 \%$ with an average tax rate $-15.9 \%$. White respondents average tax progressivity of $21.3 \%$ with an average tax rate -11.6. While African American respondents tax progressivity of $15.2 \%$ with an average tax rate of $-1.4 \%$. The CPS data shows that white $21.3 \%$ and female $21.3 \%$ CPS respondents have the highest average tax progressivity while African American respondents have the lowest $15.2 \%$. In the case of average tax rates, female CPS respondents $-15.9 \%$ have the highest rates while African American respondents $-1.4 \%$ have the lowest levels.

Table 6 shows that income inequality represented by the difference between pertax and post-tax Gini index for personal wage and salary income for years 1996 to 2011. The CPS income data clearly demonstrate that income inequality decreased for female $-20 \%$, whites $-15.0 \%$ and all $-13.1 \%$ CPS respondents while income inequality was either negotiable or increased in the case for African American respondents and African American female respondents, respectively.

Table 6. Percentage change in pre-tax and post-tax personal wage income by all race and gender for years 1996 to 2011.

\begin{tabular}{cccccccccc}
\hline Average & All & Male & Female & White & Afr. Am & White Male & White Female & Afr. Am. Male & Afr. Am. Female \\
\hline Pre-Tax Gini & 0.481 & 0.466 & 0.463 & 0.480 & 0.437 & 0.470 & 0.464 & 0.431 & 0.437 \\
Post-Tax Gini & 0.418 & 0.428 & 0.371 & 0.408 & 0.430 & 0.460 & 0.448 & 0.425 & 0.440 \\
\hline Change (\%) & -13.1 & -8.2 & -20.0 & -15.0 & -1.7 & -2.1 & -3.5 & -1.4 & 0.5 \\
\hline
\end{tabular}

Note: Author's calculations of Census Bureau's Current Population Survey (CPS) personal wage income data.

Tables 1-6 show that tax progressivity in the United States for the years 1996 to 2011 illustrates a tax system that is partly progressive and mostly regressive. Due to its regressive nature, the tax system did not display tax progressivity for the entire period under analysis for all CPS personal wage income respondents as well as when broken-down by race and gender.

\section{Conclusions}

Tax progressivity, tax policy and the redistribution of income from higher to lower income earners are economic tools to address inequality. The application of tax progressivity and macroeconomic variables to examine income distributions and income inequality has gained traction over the past decade. Income inequality is nothing new in the United States. According to the Congressional Budget Congressional Budget Office (2018) 2014 
report, income inequality is on the rise. Furthermore, the income gap between the rich and the poor has drastically widened in the advent of the Great Recession of 2008-2009. These factors brought the discourse on income inequality front and center among economists (Papanikolaou 2020).

Furthermore, tax progressivity can address the pressing issue of wage stagnation (Madrick and Papanikolaou 2010) using tax policy, specifically wages vs. capital gains to combat inequities from labor and capital earnings respectively

The empirical results using tax progressivity to measure the effects on income inequality shows moderate decrease in inequality but unevenly. African Americans had the lowest decrease in income inequality while Whites and Females had the largest declines. In the case of African American Females, income inequality had increased. It is evident from the results that a change in tax policy is required to better address income inequality across the socioeconomic spectrum. I purpose a greater increase on the marginal tax rates of the highest income earners as well as properly taxing non-earned income to have a more equitable society.

The paper was limited to personal wage income for years 1996 to 2011. Further research on tax progressivity can compare and contrast between family, household, personal income as well as race for years 1996 to 2020. By extending the focus beyond personal wage income and time series will provide robust results which allows for a more adequate tax policy to address income inequality.

Funding: This research received no external funding.

Institutional Review Board Statement: Not applicable.

Informed Consent Statement: Not applicable.

Data Availability Statement: The data was obtained from the National Bureau of Economic Research Current Population Survey (CPS) NBER CPS supplementals, https: / data.nber.org/ data/ currentpopulation-survey-data.html.

Conflicts of Interest: The author declares no conflict of interest.

Appendix A

Table A1. Variable definitions.

\begin{tabular}{|c|c|}
\hline $\begin{array}{l}\text { Current Population } \\
\text { Survey (CPS) }\end{array}$ & $\begin{array}{l}\text { The Current Population Survey (CPS), sponsored jointly by the U.S. Census Bureau and the U.S. Bureau of Labor Statistics } \\
\text { (BLS), is the primary source of labor force statistics for the population of the United States. } \\
\text { https:/ / www.census.gov/programs-surveys/cps.html }\end{array}$ \\
\hline A-RACE & $\begin{array}{l}\text { The population is divided into five groups on the basis of race: White; Black; American Indian, Eskimo or Aleut; Asian or } \\
\text { Pacific Islander; and Other races beginning with March } 1989 .\end{array}$ \\
\hline A-SEX & Defined as male or female. \\
\hline WSAL-VAL & Total wage and salary earnings value. \\
\hline WKSWORK & Weeks worked. \\
\hline A-USLHRS & How many hrs per week does ... usually work at this job? \\
\hline OCCUP & Occupation of longest job. \\
\hline LJCW & Class of worker. \\
\hline WAGEOTR & Other wage and salary earnings. \\
\hline ERN-SRCE & Source of earnings from longest job. \\
\hline ERN-VAL & Earnings before deductions, value, \\
\hline WS-VAL & Wage and salary earnings, other, amount. \\
\hline FEDTAX_AC & Federal income tax liability, after all credits. \\
\hline FEDTAX_BC & Federal income tax liability, before credits. \\
\hline $\begin{array}{l}\text { TAX } \\
\text { PROGRESSIVITY }\end{array}$ & $\begin{array}{l}\text { The distributive effects of an income tax. Progressivity takes unit-record data on pre-tax and post-tax income and computes } \\
\text { several classic measures of (net) redistributive effects, progressivity, vertical equity and reranking (horizontal inequity). } \\
\text { All indices are derived from (generalized) Gini coefficients of inequality and (generalized) concentration coefficients. }\end{array}$ \\
\hline
\end{tabular}




\section{References}

Atkinson, Anthony. 1980. Horizontal Inequity and the Distribution of the Tax Burden. In The Economics of Taxation. Edited by Henry Aaron and Michael Boskin. Washington, DC: Brookings Institution Press, pp. 3-18.

Atkinson, Anthony B. 1970. On the Measurement of Inequality. Journal of Economic Theory 3: 244-63. [CrossRef]

Auerbach, Alan J., and Daniel Feenberg. 2000. The Significance of Federal Taxes as Automatic Stabilizers. NBER Working Paper No. 7662. Available online: https:/ / papers.ssrn.com/sol3/papers.cfm?abstract_id=228136 (accessed on 12 September 2020).

Auten, Gerald, David Splinter, and Susan Nelson. 2016. Reactions of High-Income Taxpayers to Major Tax Legislation. National Tax Journal 69: 935-64. [CrossRef]

Blakey, Roy. 1938. Personal Income Taxation. By Henry C. Simons. (Chicago: The University of Chicago Press. 1938. pp. xi, 238. \$2.00.). American Political Science Review 32: 557-59. [CrossRef]

Bracewell-Milnes, Barry. 1971. The Measurement of Fiscal Policy. London: Confederation of British Industry.

Burkhauser, Richard V., Shuaizhang Feng, Stephen P. Jenkins, and Jeff Larrimore. 2008. Estimating Trends in US Income Inequality Using Current Population Survey: The Importance of Controlling for Censoring. NBER, Working Paper No. 14247. Cambridge: Center for Economics Studies (CES) Research Paper. Available online: http:/ / www.nber.org/papers/w14247 (accessed on 15 September 2020).

Congressional Budget Office. 2018. Congressional Budget Office Report. The Distribution of Household Income, 2014. Average Income before and after Mean-Tested Transfers and Federal Taxes, by Income Group, 2014. Available online: https: / www.cbo. gov/system/files/115th-congress-2017-2018/reports/53597-distribution-householdincome-2014.pdf (accessed on 20 September 2020).

Dalton, Hugh. 1954. Principles of Public Finance, 4th ed. London: Routledge and Kegan Paul Ltd., pp. 99-111.

Elwell, James, James Kevin Corinth, and Richard V. Burkhauser. 2020. Income Growth and Its Distribution from Eisenhower to Obama: The Growing Importance of In-Kind Transfers (1959-2016). In United States Income, Wealth, Consumption, and Inequality. Edited by Diana Furchtgott-Roth. Oxford: Oxford University Press, pp. 90-124.

Kakwani, Nanak. 1977a. Measurement of Tax progressivity: An International Comparison. Economic Journal 87: 71-80. [CrossRef]

Kakawani, Nanak. 1977b. Applications of Lorenz Curves in Economic Analysis. Econometrica 45: 719-27. [CrossRef]

Lambert, Peter J. 2001. The Distribution and Redistribution of Income. Manchester: Manchester University Press.

Madrick, Jeff, and Nikolaos Papanikolaou. 2010. The stagnation of male wages in the US. International Review of Applied Economics 24: 309-18. [CrossRef]

Mathews, Timothy. 2014. Historical Trends in the Degree of Federal Income Tax Progressivity in the United States. Social Science Journal 5: 90-99. [CrossRef]

Matthewson, Donald J. 2001. An analysis of john stuart mill's justification for redistribution. Paper prepared at Delivery at the 2001 Annual Meeting of the Western Political Science Association, Las Vegas, NV, USA, March 15-17.

Mill, John Stuart. 1896. Principles of Political Economy, Peoples ed. London: Langmans, Green \& Co.

Mirrlees, James A. 1971. An Exploration in the Theory of Optimal Income Taxation. Review of Economic Studies 38: 175-208. [CrossRef]

Musgrave, Richard, and Tun Thin. 1948. Income Tax Progression, 1929-48. Journal of Political Economy 56: 498-514. [CrossRef]

Musgrave, Richard A. 1959. The Theory of Public Finance. New York: McGraw Hill Book Co., pp. 532-41.

Ochmann, Richard, and Andreas Peichl. 2006. Measuring Distributional Effects of Fiscal Reforms. Finanzwissenschaftliche Diskussionsbeiträge. Cologne: Nr. FiFo Koeln, Universität zu Köln, pp. 6-9.

Papanikolaou, Nikolaos. 2020. Markov-Switching Model of Family Income Quintile Shares. Atlantic Economic Journal 48: $207-22$. [CrossRef]

Piketty, Thomas, Emmanuel Saez, and Stefanie Stantcheva. 2014. Optimal Taxation of Top Labor Incomes: A Tale of Three Elasticities. American Economic Journal: Economic Policy 6: 230-71. [CrossRef]

Plotnick, Robert. 1981. A measure of horizontal inequity. Review of Economics and Statistics 63: 283-88. [CrossRef]

Reynolds, Morgan, and Eugene Smolensky. 1977. Public Expenditures, Taxes and the Distribution of Income: The United States, 1950, 1961, 1970. New York: Academic Press.

Saez, Emmanuel, and Gabriel Zucman. 2016. Wealth Inequality in the United States since 1913: Evidence from Capitalized Income Tax Data. Quarterly Journal of Economics 131: 519-78. [CrossRef]

Slitor, Richard E. 1948. The Measurement of Progressivity and Built-in Flexibility. Quarterly Journal of Economics 62: 309-13. [CrossRef] Smith, Adam. 1776. The Wealth of Nations. Edited by Edwin Cannan. New York: Modern Library.

Suits, Daniel B. 1977. Measurement of Tax Progressivity. The American Economic Review 67: 747-52.

Vickrey, William. 1947. Agenda for Progressive Taxation. New York: The Ronald Press Co.

$\mathrm{Wu}$, Chunzan. 2020. More unequal income but less progressive taxation. Journal of Monetary Economics. in press. [CrossRef] 